\title{
The Role of Electronic Medical Records as Evidence in Medical Disputes in Hospitals
}

(Peran Rekam Medik Elektroniksebagai Alat Bukti dalam Sengketa Medik di Rumah Sakit)

Devina Anggraeni; Muhammad Ikhsan

email:17c20043@student.unika.ac.id

Health Law Master Program, Soegijapranata Catholic University of Semarang

\begin{abstract}
Medical Record is a file that contains records and other documents such as patient identification, examination, the treatment that has been given to the patient. Based on the Minister of Health No. 269/MENKES/PER /III / 2008 concerning the medical record that there are two types of medical records that conventional medical records and electronic medical records. With the absence of a strong legal basis related to the setting of electronic medical records, but in reality, many hospitals are using electronic medical records which raised the question, how the role of electronic medical records as evidence in the medical dispute that occurred in the hospital ?. This study uses Descriptio with the normative juridical approach. The data used is qualitative. This is done to get an overview of the roles of electronic medical records as evidence in the medical dispute in the hospital. Electronic medical records in the case of medical dispute resolution in the hospital can not be made as evidence in the medical case settlement, because the regulations related to the use of electronic medical records alone do not yet have a clear legal basis.
\end{abstract}

Keywords: Hospitals, Electronic Medical Records, Medical Disputes, and evidence.

\section{PENDAHULUAN}

Rumah sakit merupakan sarana pelayanan kesehatan, yang tugas utamanya melayani kesehatan perorangan di samping tugas pelayanan lainnya'.

Pengertian terkait rumah sakit juga di rumuskan pada Pasal 1 butir 1 Undang-Undang rumah sakit bahwa: "Rumah Sakit adalah institusi pelayanan kesehatan yang menyelenggarakan pelayanan kesehatan perorangan secara paripurna yang menyediakan pelayanan rawat inap, rawat jalan, dan gawat darurat". Dimana didalamnya terdapat tenaga medis yang melaksanakan pelayanan kesehatan dengan memiliki kewajiban dalam melakukan pelayan yang bermutu dan optimal, untuk mewujudkan kewajiban tersebut maka perlu dilaksanakan kewajiban yang lainnya yaitu dengan melakukan pencatatan pada berkas rekam medis dengan akurat, tepat dan bertanggung jawab.

Rekam medik (Medical Records) merupakan salah satu unsur dari trilogi rahasia kedokteran². Rekam medik atau catatan kesehatan pasien sudah ada sejak zaman dahulu. Namun keberadaannya belum menjadi kewajiban, sehingga pelaksanaan dari rekam medis belum dianggap serius ${ }^{3}$.

'Endang Wahyati Yustina, Mengenal Hukum Rumah Sakit, Bandung ; KENI media, 2012, hal,8.

${ }^{2}$ J. Guwandi.Trilogi Rahasia kedokteran. Jakarta ; Fakultas kedokteran indonesia, 1992, hlm, 31.

3J. Guwandi. Dokter dan Rumah Sakit.Jakarta ; Fakultas Kedokteran Universitas Indonesia,1999,hlm, 73. 
Secara yuridis sejak berlakunya Peraturan Menteri Kesehatan Republik Indonesia Nomor 269/MENKES/PER/III/2008 tentang Rekam Medis maka pelaksanaan rekam medik dengan membuat catatan data-data pasien sudah merupakan suatu keharusan, suatu kewajiban hukum. Catatan kesehatan pasien, ditulis oleh dokter, dan isi catatan diterima dari pasien baik dari hasil anamnesa maupun hasil dari pemeriksaan terhadap pasien, serta hasil tindakan yang diberikan oleh dokter.

Kewajiban pembuatan rekam medik semakin lama, mengakibatkan penumpukan kertas, sehingga memakan banyak tempat dan membuat kurang efektif saat mencari data pasien. Dengan seiring perubahan zaman yang semakin menuntut para tenaga kesehatan untuk profesional, cepat, dan efektif, maka rekam medis yang dulunya belum memiliki petugas yang terdidik khusus dalam bidang ini $^{4}$. Sekarang telah ada tenaga khusus untuk bidang rekam medis. Sementara untuk menangani masalah penumpukan kertas perlu mengimplementasikan kebijakan paperless system dan beralih pada rekam medis elektronik menjadi pilihan. Kebijakan paperless system menjadi bagian dari pencatatan dengan sistem teknologi, yang penggunaannya dianggap efektif bagi pelayanan kesehatan menuju pada era digitalisasi. Namun keberadaannya menimbulkan masalah lain yang sangat urgent, yaitu penggunaannyatidak mengalami perkembangan yang cepat disebabkan belum adanya kebijakan yang jelas.

Pemerintah Indonesia melalui Kementerian Kesehatan mempublikasikan Peraturan Menteri Kesehatan Republik Indonesia Nomor 269/MENKES/PER/III/2008 tentang Rekam Medis, pada Pasal 1butir (1) "menjelaskan bahwarekam medis adalah berkas yang berisikan catatan dan dokumen tentang identitas pasien, pemeriksaan, pengobatan, tindakan dan pelayanan lain yang telah diberikan kepada pasien". Serta pada Pasal 2 Ayat (1)“Rekam medis harus dibuat secara tertulis, lengkap dan jelas atau secara elektronik". Dua pasal ini menjelaskan jika berkas pada rekam medis ialah berisikan catatan kesehatan pasien yang ditulis oleh dokter dan bukan merupakan hasil dari ketikan pada alat teknologi.Pasal 2 Ayat (2) menjelaskan bahwa "penyelenggaraan rekam medis dengan menggunakan teknologi informasi elekronik diatur lebih lanjut dengan peraturan sendiri". Namun regulasi ini tidak memberi detail lengkap tentang rekam medis elektronik 5 .

Selain itu ketentuan tentang rekam medis elektronik terdapat dalam Pasal 9 UndangUndang Nomor 11 Tahun 2008 tentang Informasi dan Transaksi Elektronik, dijelaskan bahwa "Pelaku usaha yang menawarkan produk melalui Sistem Elektronik harus menyediakan informasi yang lengkap dan benar berkaitan dengan syarat kontrak, produsen, dan produk yang ditawarkan". Dalam pasal ini menjelaskan bahwa penulisan informasi pasien meliputi hal-hal yang terkait dalam rekam medis harus sesuai, sehingga kelengkapan data sangat diperlukan. Perlindungan hukum terhadap data pasien mengenai privacy, confidentiality serta keamanan informasi pasien secara umum, masih belum memiliki payung hukum yang jelas ${ }^{6}$.

Di Indonesia Pengaturan rekam medis elektronik secara khusus belum di atur namun dalam prakteknya di lapangan sudah ada beberapa rumah sakit yang menerapakan rekam medik electronik, kemudian bagaimana kekuatan rekam medik elektronik untuk alat bukti di dalam persidangan ketika terjadi sengketa medis.

\footnotetext{
Ibid

Seminar nasional paperless healthcare system in Indonesia. Unika Soegijapranata. Semarang.2 Maret 2019.
}

6 lbid 


\section{RUMUSAN MASALAH}

Bagaimana Peran Rekam Medik Elektronik Sebagai Alat Bukti Dalam Sengketa Medik Di Rumah Sakit?

\section{METODE PENELITIAN}

Metodologi penelitian adalah cara ilmiah (rasional, empiris, dan sistematis) yang digunakan oleh penganut suatu disiplin ilmu untuk melakukan penelitian ${ }^{7}$. Dalam menyusun penelitian ini metode yang digunakan penulis ialah sebagai berikut :

1. Metode pendekatan

Dengan menggunakan metode pendekatan yuridis normatif. Berupa pendekatan yang bersifat kepustakaan, yaitu penelitian terhadap data sekunder ${ }^{8}$.

2. Spesifikasi penelitian

Spesifikasi penelitian ini adalah penelitian deskriptif, yaitu penelitian yang mendiskriptifkan peristiwa hukum serta mengkajinya secara tersistematis sehingga dengan mudah di pahami dan di simpulkan.

3. Jenis data

Penelitian pada umumnya dapat dibedakan menjadi dua yaitu data yang diperoleh secara langsung dari masyarakat serta data yang diperoleh dari bahan-bahan pustaka. Yang diperoleh secara langsung disebut dengan data primer (atau data dasar), sementara data yang diperoleh dari bahan-bahan pustaka lazimnya dinamakan data sekunder. ${ }^{9,10}$ Karena metode pendekatan yang digunakan pada penelitian ini yaitu yuridis normatif maka sumber dan jenis datanya itu berfokus pada data sekunder. Bahan-bahan hukum dalam penelitian ini meliputi bahan hukum primer, sekunder serta tersier.

a. Bahan hukum primer, yaitu:

1) Undang-Undang Republik Indonesia Nomor 29 Tahun 2004 Tentang Praktek Kedokteran.

2) Undang-Undang Republik Indonesia Nomor 11 Tahun 2008 Tentang Informasi dan Transaksi Electronik

3) Undang-Undang Republik Indonesia Nomor 44 Tahun 2009 Tentang Rumah Sakit

4) Undang-Undang Republik Indonesia Nomor 36 Tahun 2014 Tentang Tenaga Kesehatan

5) Peraturan Menteri Kesehatan Republik Indonesia Nomor 269 Tahun 2008 Tentang Rekam Medis.

b. Bahan hukum sekunder yaitu bahan hukum yang erat hubungannya dengan bahan hukum primer dan dapat membantu menganalisis dan memahami bahan hukum primer $^{11}$, seperti :

Buku - buku, literatur, artikel, hasil penelitian dan tulisan-tulisan yang berhubungan dengan rekam medis elektronik.

\footnotetext{
7 V. Wiratna Sujarweni, Metodologi Penelitian; Lengkap Praktis dan Mudah Dipahami, Yogyakarta ; Pustaka Baru Press, 2014, hlm.5

8 Ronny Hanitijo Soemitri, Metodologi Penelitian Hukum Dan Jurimetri, Jakarta ; Ghalia Indonesia, 1994, hlm,11.

9 Soerjono Soekanto dan Sri Mamudji, Penelitian Hukum Normatif, Jakarta ; CV. Rajawali, 1985, hlm, 14.

${ }^{10}$ Rianto adi, Metode Penelitian Sosial dan Hukum, Jakarta ; Granit, 2004,hlm, 57.

${ }^{11}$ Ronny Hanitijo Soemitri, op. cit., hal,12
} 
c. Bahan hukum tersier yaitu bahan hukum yang memberikan informasi tentang bahan hukum primer juga bahan hukum sekunder ${ }^{12}$, seperti : kamus hukum, jurnal hukum, dan lain-lain.

4. Metode pengumpulan data

Pengumpulan data merupakan hal yang sangat erat hubungannya dengan sumber data. Berkaitan penelitian yang di buat oleh penulis yaitu penelitian yuridis normatif maka metode pengumpulan data berdasarkan pada data sekunder, yaitu dengan dengan cara study pustaka dan masalah-masalah hukum terkait rekam medis yang telah di bukukan.

5. Metode analisis data

Analisia data secara garis besar itu terbagi atas dua yaitu analisis kualitatif dan analisis kuantitatif. Karena penelitian ini menggunakan pendekatan normatif, maka analisis datanya adalah kualitatif normatif. ${ }^{13}$ Analisis kualitatif adalah analisis yang tidak didasarkan pada angka atau kuantitas ${ }^{14}$.

\section{PEMBAHASAN}

\section{Rekam Medis Elektronik (RME)}

Unsur kedua dari trilogi rahasia kedokteran adalah rekam medik (Medical Records). Datadata dalam Medical Records bersifat rahasia (Confidential) karena hubungan pasien dokter bersifat khusus dan segala sesuatu yang dipercayakan oleh pasien kepada dokter untuk dilindungi terhadap pengungkapan lebih lanjut. Hal ini sudah ada sejak zaman hippocrates ${ }^{15}$.

Rekam medis merupakan hasil dari hubungan dua arah yaitu dokter dan pasien. Hubungan antara dokter dan pasien memunculkan dua macam hubungan yaitu dimana hubungan pertama merupakan hubungan hukum yang terjadi karena kontrak terapeutik yang disebabkan oleh adanya peraturan perundang-undangan. Sedangkan yang kedua muncul akibat dari adanya kewajiban yang ditanggung oleh dokter karena profesinya.

Rekam medis elektronik/rekam kesehatan elektronik merupakan suatu pencatatan yang pelaksanaannya menggunakan komputerisasi. Kebutuhan akan informasi yang cepat serta akurat, telah menjadi keperluan yang utama untuk setiap orang. Salah satunya ialah sistem informasi rumah sakit. Sistem ini di sebut dengan sistem informasi medis,atau dengan kata lainHospital Information System (HIS). Sistem yang dimaksud ialah sebuah sistem yang jangkauannya tidak hanya di dalam tapi juga diluar rumah sakit. Adapun fungsi dari HIS ialah sebagai perangkat yang dapat mengelola data inpatient dan outpatient serta mengelola data medis pasien yang meliputi perawatan, diagnosis, dan terapi ${ }^{16}$.

Rekam medis sebagaimana yang dinyatakan dalam Pasal 46 ayat (1) Undang-Undang Republik Indonesia Nomor 29 Tahun 2004 Tentang Praktik Kedokteran, "berkas yang berisi catatan dan dokumen tentang identitas pasien, pemeriksaan, pengobatan, tindakan dan pelayanan lain yang telah diberikan kepada pasien".Pasal 1 poin 1 Peraturan Menteri Kesehatan Republik Indonesia Nomor 269/MENKES/PER/III/2008 tentang Rekam Medis adalah berkas yang berisi catatan dan dokumen lain seperti identitas pasien, hasil

\footnotetext{
${ }^{12}$ ibid., hal,12

${ }^{13}$ Agnes Widanti, Petunjuk Penulisan Usulan Penelitian dan Tesis, Semarang ; UNIKA, 2015, hlm,9.

${ }^{14}$ Ibid., hlm, 10.

15J. Guwandi. Trilogi Rahasia kedokteran. Jakarta ; Fakultas kedokteran indonesia. 1992, hlm, 31.

${ }^{16}$ Sri Kusumadewi, dkk. Informatika Kesehatan. Graha Ilmu. Yogyakarta. 2009. HIm 5
} 
pemeriksaan, pengobatan yang telah diberikan kepada pasien. Catatan yang dimaksud ialah tulisan-tulisan yang dibuat oleh dokter dan dokter gigi, dan/atau tenaga kesehatan lainnya yang telah diterima oleh pasien ${ }^{17}$.

Rekam medis ialah catatan yang mencerminkan setiap informasi pasien, oleh dokter, dokter gigi maupun tenaga kesehatan lain dijadikan dasar sebagai penentu dari tindakan lebih lanjut yang bertujuan untuk upaya dari pelayanan kesehatan atau tindakan medis yang diberikan kepada seorang pasien.

Sedangkan pendapat dari teknis medis, bahwa rekam medis merupakan keterangan tentang pasien, baik dalam bentuk tertulis maupun yang terekam. Adapun isi dalam rekam medis meliputi identitas, anamnesa, laporan laboratorium maupun hasil pemeriksaan penunjang lainnya, serta diagnosis juga tindakan medik meliputi pengobatan dan perawatanyang telah diterima oleh pasien dan pengobatan baik pasien rawat inap, rawat jalan, dan pelayanan gawat darurat ${ }^{18}$.

Jenis rekam medis menurut Peraturan Menteri Kesehatan Nomor 269 Tahun 2008 tentang Rekam Medik, ada dua jenis rekam medik yaitu pertama rekam medis konvensional rekam medik ini ditulis menggunakan sarana kertas dan rekam medis elektronik yang penulisannya menggunakan alat elektronik seperti komputer.

Rekam medis merupakan salah satu dari subsistem yang ada dalam HIS. Electronic Medical Record (EMR) merupakan suatu rekam medis dalam bentuk elektronik yang di manfaatkan sebagai media untuk menyimpan informasi klinis seperti, merekam informasi, mengakses informasi, membantu pengambilan keputusan, menggunakan data atau informasi secara bersama-sama, identifikasi pasien, menangani keamanan dan otentifikasi data, juga membantu proses auditing ${ }^{19}$.

Beberapa tipe dari data dan informasi rekam medis elektronik, yaitu:

1. Tipe data tekstual.

2. Tipe grafis.

3. Tipe digital ${ }^{20}$

Masalah yang sering muncul dalam penggunaan rekam medis elektronik yaitu kesalahan, kelalaian, ketidakpastian serta variasi dari pasien dan klinisi ${ }^{21}$. Dengan bertambahnya data rekam medis setiap harinya yang berakibat pada kesulitan dalam mengakses data atau menganalisis data rekam medis pasien tertentu dengan masalah tertentu pula.

Adapun isi dari rekam medis elektronik sama dengan isi rekam medis konvensional, meliputi; pengumpulan, pengolahan, analisis dan mempresentasikan data yang semuanya berhubungan dengan kegiatan pelayanan kesehatan yang telah dilakukan dan diberikan kepada pasien. Tentu saja adanya rekam medis elektronik ini memiliki peran yang sangat penting untuk memudahkan setiap pengobatan pasien yang berada di tempat yang berbeda dengan rekam medis miliknya. Contohnya saat seorang pasien berada di kota A, namun rekam medis miliknya berada di kota $B$, sementara ia memerlukan rekam medis tersebut untuk melakukan pengobatan di kota A, maka pasien dapat meminta pemegang

\footnotetext{
${ }^{17}$ Sri Siswati. Etika dan Hukum Kesehatan dalam Perspektif Undang-Undang Kesehatan. Ed.1-Cet.1. Jakarta; Rajawali Pers, 2013, hlm 109-110.

${ }^{18}$ Hendrik, 2014. Etika Hukum Kesehatan; Penerbit Buku Kedokteran EGC : Jakarta. hal.82.

${ }^{19} \mathrm{lbid}$

${ }^{20} \mathrm{Ibid} ., \mathrm{hlm} 6$

${ }^{21}$ lbid
} 
rekam medis miliknya (pemberi layanan kesehatan di kota B yaitu dokter) untuk mengirimkannya melalui media elektronik. Berkaitan dengan hal diatas, pasien memang memiliki hak untuk dapat mengakses atau melihat informasi kesehatan pribadinya.Dengan contoh diatas dapat dikatakan bahwa rekam medis merupakan suatu hal yang sangat penting dalam pelayanan medis, dimana keberadaan rekam medis menjadi sebuah panduan untuk dokter, dokter gigi maupun pelayanan kesehatan lainnya dalam memberikan pelayanan kesehatan.

Keberadaan rekam medis bukan sebagai suatu layanan kesehatan, namun merupakan catatan kesehatan yang bisa digunakan sebagai alat untuk menentukan pengobatan serta perawatan. Tidak hanya itu saja rekam medis juga merupakan bukti dari pengobatan dan perawatan yang telah diterima oleh pasien dari layanan kesehatan. Perlu adanya pemahaman lebih dahulu terkait pemilik isi rekam medis serta siapa yang berhak dalam pengisian rekam medis yang ada.

Adapun orang-orang yang yang terkait dengan atas rekam medis yaitu pasien, dokter dan dokter gigi, serta tenaga kesehatan. Sesuai dengan regulasi yang tertuang didalam Permenkes RI Nomor 269/Menkes/Per/III/2008 terdapat keterangan lebih lanjut tentang ketiga orang yang memiliki hak akan rekam medis. Dalam Pasal 1 ayat (5) dijelaskan bahwa pasien merupakan setiap orang yang melakukan konsultasi masalah kesehatannya untuk memperoleh pelayanan kesehatan yang diperlukan baik secara langsung maupun tidak langsung kepada dokter atau dokter gigi. Dalam Pasal 1 ayat (2) disebutkan bahwa dokter dan dokter gigi didefenisikan sebagai dokter, dokter spesialis, dokter gigi dan dokter gigi spesialis lulusan pendidikan kedokteran atau gigi baik di dalam maupun di luar negeri yang diakui oleh Pemerintah Republik Indonesia sesuai dengan peraturan perundang-undangan. Serta Pasal 1 ayat (4) tenaga kesehatan tertentu dapat didefenisikan sebagai tenaga kesehatan yang ikut memberikan pelayanan kesehatan secara langsung kepada pasien selain dokter dan dokter gigi.

\section{Penerapan Rekam Medis Elektronik Di Rumah Sakit}

Perkembangan teknologi digital yang sangat pesat berakibat pula pada layanan kesehatan yang juga ikut berpartisipasi dalam pemanfaatannya. Data yang terekam melalui alat dapat segera di manfaatkan dengan mudah serta biaya yang juga relatif murah ${ }^{22}$.

Beberapa rumah sakit di Indonesia sudah menerapkan rekam medis berbasis elektronik dengan memanfaatkan sistem informasi kesehatan. Adopsi sistem informasi rekam medis di Indonesia dapat dikatakan mengalami keterlambatan yang diakibatkan oleh berbagai isu, seperti kompleksitas, biaya, privasi, keamanan, kerahasiaan, belum adanya standar serta kebijakan dari peraturan terkait penggunaan rekam medis elektronik ${ }^{23}$.

\section{A. Pengaturan Hukum Rekam Medis Elektronik Di Indonesia}

Pengaturan rekam medis electronik di indonesia secara khusus belum di aturnamun dalam prakteknya di lapangan sudah ada beberapa rumah sakit yang menerapakan rekam medik electronik,ada beberapa peraturan yang di jadikan alasan oleh rumah sakit yang menerapkan rekam medis elektronik, antara lain ;

\footnotetext{
${ }^{22}$ Sri Kusumadewi, dkk. Informatika Kesehatan. Graha Ilmu. Yogyakarta. 2009. HIm 10.

${ }^{23}$ Raghupathi, 2003. Dalam Sri Kusumadewi, dkk. Informatika Kesehatan. Graha Ilmu. Yogyakarta. 2009. HIm 42.
} 
1. Undang-Undang Republik Indonesia Nomor 29 Tahun 2004 tentang Praktek Kedokteran

Pasal 46;

1) "Setiap dokter atau dokter gigi dalam menjalankan praktek kedokteran wajib membuat rekam medis.

2) Rekam medis sebagaimana dimaksud pada ayat (1) harus segera dilengkapi setelah pasien selesai menerima pelayanan kesehatan.

3) Setiap catatan rekam medis harus dibubuhi nama, waktu, dan tanda tangan petugas yang memberikan pelayanan atau tindakan".

Pasal 47;

1) "Dokumen rekam medis sebagaimana dimaksud dalam pasal 46 merupakan milik dokter, dokter gigi atau sarana pelayanan kesehatan, sedangkan isi rekam medis merupakan milik pasien.

2) Rekam medis sebagaimana dimaksud pada ayat (1) harus disimpan dan dijaga kerahasiaannya oleh dokter atau dokter gigi dan pimpinan sarana pelayanan kesehatan.

3) Ketentuan mengenai rekam medis sebagaimana dimaksud pada ayat (1) dan ayat (2) diatur dengan Peraturan Menteri".

2. Undang-Undang Republik Indonesia Nomor 11 Tahun 2008 tentang Informasi dan Transaksi Electronik.

Pasal 6

"Pasal 6 Dalam hal terdapat ketentuan lain selain yang diatur dalamPasal 5 ayat (4) yang mensyaratkan bahwa suatu informasi harus berbentuk tertulis atau asli, Informasi Elektronik dan/atau Dokumen Elektronik dianggap sah sepanjang informasi yang tercantum di dalamnya dapat diakses, ditampilkan, dijamin keutuhannya, dan dapat dipertanggungjawabkan sehingga menerangkan suatu keadaan."

Pasal 11

(1) “Tanda Tangan Elektronik memiliki kekuatan hukum dan akibat hukum yang sah selama memenuhi persyaratan sebagai berikut:

a. data pembuatan Tanda Tangan Elektronik terkait hanya kepada Penanda Tangan;

b. data pembuatan Tanda Tangan Elektronik pada saat proses penandatanganan elektronik hanya berada dalam kuasa Penanda Tangan;

c. segala perubahan terhadap Tanda Tangan Elektronik yang terjadi setelah waktu penandatanganan dapat diketahui;

d. segala perubahan terhadap Informasi Elektronik yang terkait dengan Tanda Tangan Elektronik tersebut setelah waktu penandatanganan dapat diketahui;

e. terdapat cara tertentu yang dipakai untuk mengidentifikasi siapa Penandatangannya; dan

f. terdapat cara tertentu untuk menunjukkan bahwa Penanda Tangan telah memberikan persetujuan terhadap Informasi Elektronik yang terkait. 
(2) Ketentuan lebih lanjut tentang Tanda Tangan Elektronik sebagaimana dimaksud pada ayat (1) diatur dengan Peraturan Pemerintah".

Pasal 16

(1) Sepanjang tidak ditentukan lain oleh undang-undang tersendiri, setiap Penyelenggara Sistem Elektronik wajib mengoperasikan Sistem Elektronik yang memenuhi persyaratan minimum sebagai berikut:

a. dapat menampilkan kembali Informasi Elektronik dan/atau Dokumen Elektronik secara utuh sesuai dengan masa retensi yang ditetapkan dengan Peraturan Perundang-undangan;

b. dapat melindungi ketersediaan, keutuhan, keotentikan, kerahasiaan, dan keteraksesan Informasi Elektronik dalam Penyelenggaraan Sistem Elektronik tersebut;

c. dapat beroperasi sesuai dengan prosedur atau petunjuk dalam Penyelenggaraan Sistem Elektronik tersebut;

d. dilengkapi dengan prosedur atau petunjuk yang diumumkan dengan bahasa, informasi, atau simbol yang dapat dipahami oleh pihak yang bersangkutan dengan Penyelenggaraan Sistem Elektronik tersebut; dan

e. memiliki mekanisme yang berkelanjutan untuk menjaga kebaruan, kejelasan, dan kebertanggungjawaban prosedur atau petunjuk.

(2) Ketentuan lebih lanjut tentang Penyelenggaraan SistemElektronik sebagaimana dimaksud pada ayat (1) diatur dengan Peraturan Pemerintah.

3. Peraturan Menteri Kesehatan Republik Indonesia Nomor 269 Tahun 2008 tentang Rekam Medis.

Pasal 1 angka1

"Rekam medis adalah berkas yangberisikan catatan dan dokumen tentang identitas pasien, pemeriksaan, pengobatan, tindakan, dan pelayanan lain yang telah diberikan kepada pasien".

Pasal 2 ayat (1)

"Rekam

Permenkes ini dikeluarkan untuk menunjang dalam peningkatan mutu pelayanan kesehatan yang mengatur terkait rekam medis sehingga dapat terwujud keseragaman dalam pelaksanaan rekam medis di Indonesia.

Perundang-undangan yang ada telah mengatur mengenai pelaksanaan rekam medis baik yang manual ataupun elektronik walaupun untuk elektronik belum ada pengaturan secara khusus dengan demikian apabila terjadi permasalahan yang muncul dari pelaksanaan rekam medis elektronik di rumah sakit maka di pakaiperaturan yang dapat melindungi pasien bila terjadi kerugian pada pasien sebab pengaturan yang ada sudah cukup jelas.

Data rekam medis elektronik memiliki kedudukan yang sama dengan rekam medis manual sebagaimana dijelaskan bahwa rekam medis elektronik termasuk kategori dokumen elektronik berdasarkan yang dimuat dalam Undang-Undang No. 11 Tahun 2008 tentang Informasi dan Transaksi Elektronikmerupakan dasar hukum yang dapat 
diterapkan terhadap rekam medis elektronik. Menurut Pasal 44 UU ITE alat bukti yang sah selain yang ditentukan peraturan perundang-undangan termasuk juga alat bukti lain berupa informasi elektronik danatau dokumen elektronik.

\section{B. Rekam Medis Elektronik Sebagai Alat Bukti}

Pembuktian dalam perkara pidana tidak sama dengan pembuktian dalam perkara perdata. Dalam pembuktian perkara pidana (hukum acara pidana) adalah bertujuan untuk mencari kebenaran materiil, yaitu kebenaran sejati atau yang sesungguhnya, hakim pidana dalam mencari kebenaran materiil, maka peristiwanya harus terbukti (beyond reasonable doubt) ${ }^{24}$.

Menurut Andi Hamzah Ada empat teori dalam sistem pembuktian di dalam hukum acara pidana yaitu, Sistem atau teori berdasarkan berdasarkan Undang-undang secara posoitif (positive wetteljik bewijstheorie), Sistem atau teori pembuktian berdasarkan keyakinan hakim saja (conviction intime), Sistem atau teori pembuktian berdasarkan keyakinan hakim dengan alasan yang logis (laconviction raisonnee) dan Sistem atau teori pembuktian berdasarkan Undang-undang secara negatif (negatief wettellijk bewijs theotrie).

Kekuatan pembuktian dalam hukum acara pidana terletak didalam Pasal 183 Undangundang Nomor 8 Tahun 1981 tentang Hukum Acara Pidana, yang berbunyi "hakim tidak boleh menjatuhkan pidana kepada sesorang kecuali apabila dengan sekurang-kurangnya dua alat bukti yang sah ia memperoleh keyakinan bahwa suatu tindak pidana benar-benar terjadi dan bahwa terdakwalah yang bersalah melakukannya". Berdasarkan ketentuan diatas maka seorang hakim dalam memutuskan suatu perkara pidana harus memiliki minimal dua alat bukti yang sah. Apabila hakim tidak memiliki dua alat bukti tersebut maka terdakwa tidak dapat diajutuhi hukuman atas tindakannya.

Adapun alat bukti yang sah sebagaimana yang diatur dalam Pasal 184 ayat (1) Undang Undang Nomor 8 Tahun 1981 tentang Hukum Acara Pidana, yaitu sebagai berikut: keterangan saksi, keterangan ahli, surat, petunjuk dan keterangan terdakwa. Semua alat bukti yang dimaksud mempunyai kekuatan yang sama dipersidangan acara pidana.

Dalam awal perkembangan dunia kedokteran di Indonesia, rekam medis tidak menjadi suatu alat penunjang yang penting untuk menilik status kesehatan pasien yang dapat dijadikan sebagai penentu pengobatan dan perawatan karena kurang mendapat perhatikan. Untuk pencatatan data medis instansi pelayanan kesehatan hanya menggunakan kartu pasien yang disebut dengan istilah "status". Adapun penyebab utamanya akibat dahulu rekam medis tidak begitu penting karena belum menciptakan persoalan. Namun, seiring berkembangnya zaman, masyarakat mulai menyadari pentingnya rekam medis. Sebelumnya hampir tidak pernah ada gugatan terhadap pemberi layanan kesehatan, sementara saat ini dengan berkembangnya zaman terutama dibidang kesehatan dan teknologi membuat masyarakat yang dulunya hanya percaya terhadap suatu takdir dan tidak menganggap suatu kecacatan maupun kematian sebagai sebuah kelalaian medis. Dengan sadarnya akan pentingnya kesehatan dan menjadikannya mengerti bahwa yang terjadi merupakan sebuah kerugian, diakibatkan oleh tindakan kedokteran sehingga pasien maupun keluarganya banyak melayangkan

\footnotetext{
${ }^{24}$ Andi Sofyan, Hukum Acara Pidana Suatu Pengantar. Yogyakarta: Rangkang Education, 2013. hlm, 241.
} 
gugatan terhadap pemberi layanan kesehatan. Gugatan-gugatan yang dilayangkan tersebut melibatkan rekam medis sebagai alat bukti.

Setiap layanan kesehatan yang dilakukan atau diberikan oleh dokter dan/atau dokter gigi terhadap pasien semuanya memiliki standar. Standar yang dimaksudkan yaitu standar yang dikenal dengan istilah standar profesi. Dimana setiap tindakan yang dilakukan atau diberikan oleh dokter terhadap pasien seharusnya sesuai dengan standar profesinya. Jadi tindakan dokter kepada pasien selain dipertanggungjawabkan kepada pasien, juga dipertanggungjawabkan kepada Majelis Kode Etik Kedokteran Indonesia.

Dokter memiliki tanggungjawab secara hukum terkait rekam medis, yaitu tanggung jawab dari profesi dan etika dokter. Dimana dokter atau dokter gigi yang melakukan kesalahan baik berupa pelanggaran maupun kelalaian bisa dituntut secara perdata, pidana dan administratif. Selain pada pengadilan dokter atau dokter gigi juga bisa dilaporkan kepada Pengadilan Etik yaitu organisasi profesi dan pengadilan disiplin profesi.

Maka ketika terjadi sengketa medik, rekam medis dapat digunakan sebagai alat bukti untuk membuktikan atau mengungkap kesalahan medis yang terjadi. Karena selain sebagai catatan pasien untuk menentukan perawatan dan pengobatan juga berfungsi untuk memberi kepastian hukum berlandas atas keadilan yang dapat menjadi acuan setiap layanan kesehatan dalam memberi pelayanan kesehatan. Sehingga setiap kesalahan medis yang terjadi dapat dipertanggungjawabkan.

Rekam medis adalah alat bukti tertulis paling utama dalam menyelesaikan permasalahan hukum, pelanggaran disiplin dan etika profesi. Selain itu, rekam medis bisa digunakan sebagai dokumen medis jika terjadi konflik yang berkaitan dengan hukum baik di pengadilan profesi maupun di pengadilan negeri. Pernyataan tersebut sesuai dengan Pasal 13 ayat (1) butir (b) Permenkes RI Nomor 269/Menkes/Per/III/2008 yang menyebutkan bahwa pemanfaatan rekam medis dapat dipakai sebagai alat bukti dalam proses penegakan hukum, disiplin kedokteran dan kedokteran gigi dan penegakan etika kedokteran dan etika kedokteran gigi. Dengan peraturan ini, bahwa untuk pemberi layanan kesehatan, rekam medis bisa digunakan sebagai alat untuk memberikan pembelaan dan keterangan pembenaran yang tertulis terhadap adanya tugas profesi yang dijalankan dengan baik, dan tidak ada kelalaian dari tindakan yang telah diberikan serta telah sesuai dengan standar profesi yang telah mendapat persetujuan dari pasien atau keluarganya. Disamping itu bagi pasien sendiri, berkas rekam medis bisa digunakan pasien atau keluarganya atas hukum sebagai dasar untuk melakukan gugatan hukum atau penuntutan perkara di pengadilan dengan tata cara hukum yang berlaku.

Rekam medis elektronik sebagai alat bukti di pengadilan masih menjadi masalah yaitu bahwa tanda tangan yang diperlukan ialah yang asli, bukan paraf, scan atau tanda tangan elektronik. Jadi jelas dikatakan bahwa rekam medis adalah catatan yang atau ditulis dengan pena dan tidak di ketik menggunakan alat elektronik, bahkan jika di ketik pada media elektronik wajib hukumnya untuk mencatat kembali pada kertas, jika tidak terdapat catatan selain pada media elektronik dapat dianggap sebagai sebuah kejahatan ${ }^{25}$.

${ }^{25}$ Wila Chandrawila. Dalam Seminar Nasional Paperless Healthcare System In Indonesia. Unika Soegijapranata. Semarang. 2 Maret 2019. 


\section{KESIMPULAN}

Rekam medis adalah alat bukti tertulis paling utama dalam menyelesaikan permasalahan hukum, pelanggaran disiplin dan etika profesi. Rekam medis elektronik pada kasus penyelesaian sengketa medis di rumah sakit tidak dapat di jadikan sebagai alat bukti dalam penyelesai perkara medik, sebab peraturan terkait penggunaan rekam medik elektronik sendiri belum memiliki dasar hukum yang jelas sehingga rumah sakit yang telah melaksanakan rekam medik elektronik penggunaannya masih hasrus bersamaan dengan rekam medik konvensional jika tidak di anggap sebagai suatu kejahatan yang dilakukan oleh tenaga medis di rumah sakit.

\section{SARAN}

Dengan banyaknya rumah sakit yang telah menerapkan rekam medis elektronik, perlu di buatnya regulasi tentang rekam medis elektronik. Sementara rumah sakit yang telah menerapkan rekam medis elektronik, perlu pemberitahuan dari pemerintah bahwa penggunaannya masih harus bersamaan dengan pembuatan rekam medis konvensional.

\section{DAFTAR PUSTAKA}

\section{Buku-Buku}

Agnes Widanti, 2015. Petunjuk Penulisan Usulan Penelitian dan Tesis, Semarang ; UNIKA.

Andi Sofyan, 2013. Hukum Acara Pidana Suatu Pengantar. Yogyakarta: Rangkang Education.

Endang Wahyati Yustina, 2012. Mengenal Hukum Rumah Sakit, Bandung ; KENI media.

Hendrik, 2014. Etika Hukum Kesehatan; Penerbit Buku Kedokteran EGC : Jakarta.

J. Guwandi,1999. Dokter dan Rumah Sakit. Jakarta ; Fakultas Kedokteran Universitas Indonesia.

J. Guwandi, 1992.Trilogi Rahasia kedokteran. Jakarta ; Fakultas kedokteran indonesia,

J. Guwandi. 1992. Rahasia Medis. Jakarta ; Fakultas kedokteran indonesia.

Rianto adi, 2004.Metode Penelitian Sosial dan Hukum, Jakarta ; Granit.

Ronny Hanitijo Soemitri, 1994.Metodologi Penelitian Hukum Dan Jurimetri, Jakarta ; Ghalia Indonesia.

Seminar nasional paperless healthcare system in Indonesia. Unika Soegijapranata. Semarang. 2 Maret 2019.

Soerjono Soekanto dan Sri Mamudji, 1985.Penelitian Hukum Normatif, Jakarta ; CV. Rajawali.

Sri Kusumadewi, dkk., 2009.Informatika Kesehatan. Graha Ilmu. Yogyakarta.

Sri Siswati. 2013. Etika dan Hukum Kesehatan dalam Perspektif Undang-Undang Kesehatan. Ed.1-Cet.1. Jakarta; Rajawali Pers.

V. Wiratna Sujarweni, 2014.Metodologi Penelitian; Lengkap Praktis dan Mudah Dipahami,Yogyakarta ; Pustaka Baru Press, 
SOEPRA Jurnal Hukum Kesehatan

ISSN:2548-818X (media online) Vol. 5 (2) Desember 2019

\section{Peraturan Perundang-undangan}

Undang-Undang Republik Indonesia Nomor 29 Tahun 2004 Tentang Praktek Kedokteran.

Undang-Undang Nomor 11 Tahun 2008 Tentang Informasi Dan Transaksi Elektronik

Undang-Undang Republik Indonesia Nomor 44 Tahun 2009 Tentang Rumah Sakit

Undang-Undang Republik Indonesia Nomor 36 Tahun 2014 Tentang Tenaga Kesehatan

Peraturan Menteri Kesehatan Republik Indonesia Nomor 269/Menkes/PER/III/2008 Tentang Rekam Medis 